\title{
Analysis of Raw Material Inventory Control Using Economic Order Quantity (EOQ) Method at CV. XYZ
}

\author{
$1^{\text {st }}$ Wahyu Sidiq Saputra, $2^{\text {nd }}$ Rieska Ernawati, $3^{\text {rd }}$ Wiwik Anggraini Wulansari \\ ${ }^{1.2}$ Program Studi Teknik Industri, Universitas Selamat Sri Kendal, Indonesia \\ Email: wiwikanggrainiwulansari@gmail.com
}

\begin{abstract}
Companies need a control over their products in maintaining the quality and quantity, to be able to always meet the demands and needs of consumers. CV. XYZ is a digital printing company which is located at Jl. Sunan Abinawa, Patebon District, Kendal Regency (in front of SMP 2 Patebon). Raw material inventory control in CV. XYZ still uses the manual calculation method. With the Economis Order Quantity (EOQ), the inventory of raw materials can be kept to a minimum, the cost is as low as possible, and the quality is better. Based on the results of research and data analysis shows that the application of the EOQ method in CV.XYZ can produce inventory cost efficiency. This means that the raw material procurement policy carried out by CV. XYZ so far has not been efficient and has not shown minimum costs. While the inventory costs that have been issued by the company are still greater when compared to companies implementing raw material inventory control using the EOQ method. The total cost of inventory issued based on company policy is Rp. 14,899,999, while by using the EOQ calculation method the total inventory of paper raw materials can be made smaller, namely as much as 45.4 with orders 4 times a year.
\end{abstract}

Keywords: Inventory control, raw materials, Economic Order Quantity Method

\section{INTRODUCTION}

Along with advances in technology, society's need for information also increases. Due to this situation the demand for printed materials such as browsers is increasing. Companies must prepare raw materials to anticipate the increase in demand. Product control activities are very necessary, such as checking the quantity of inventory in the warehouse, as well as selecting defective raw materials so that unexpected situations do not occur (Darmawan, 2015).

The discussion of a special review of this research discusses "Analysis of Raw Material Inventory Control Using Economic Order Quantity (EOQ) Method at CV. $X Y Z "$. To be able to find out how to control raw material inventory in CV. XYZ. Based on initial observations in CV. XYZ, it can be seen that the raw material inventory control in CV. XYZ still uses the manual calculation method. With this manual calculation, the frequency of purchasing raw materials in one period, the time of purchase, the amount of raw materials purchased in each purchase, the minimum amount of raw materials that must be in safety stock, and when to reorder or reorder point of raw materials cannot be determined precisely (Prihasdi, 2012).

In producing $\mathrm{CV}$ products. XYZ uses various types of raw materials, including paper, ink, MMT and other materials. Orders are adjusted to the inventory of goods in the warehouse. The use of the EOQ method in controlling raw material inventory will be able to minimize the occurrence of out of stock so that the production process can run smoothly and can realize the efficiency of raw material inventory (Prihasdi, 2012).

\section{THEORITICAL REVIEW}

Inventory is stock or storage of goods that are kept by the company in inventory related to the business being carried out (Stevenson and Chuong, 2014). Inventory has a number of functions according to Stevenson and Chuong (2014), the most important of which are to meet expected customer demand, streamline production requirements, segregate operations, protect against stockouts, take advantage of order cycles, protect against price increases, enable operations, and to take advantage of quantity discounts. Inventory is goods or materials which are one of the assets of the organization that are stored in anticipation of meeting demand (Handoko, 2011).

According to Render and Heizer (2005), there are four inventory functions, as follows:

a. Decouple or separate various parts of the production process. For example, if a company's supply fluctuates, it may need additional inventory to decouple the production process from suppliers.

b. Decouple the company from fluctuations in demand and provide supplies of goods that will provide choice for customers. This kind of inventory generally occurs in retail traders.

c. Take advantage of quantity discounts, because purchasing in larger quantities can reduce the cost of producing or shipping goods.

d. Maintain the influence of inflation and rising prices. According to Render and Heizer (2005), based on the manufacturing process, inventory is divided into four types, namely:

a. Inventory of raw materials (raw material inventory). Is inventory purchased but not processed. This 


\section{International Journal of Computer and Information System (IJCIS)}

Peer Reviewed - International Journal

Vol : Vol. 02, Issue 03, August 2021

e-ISSN : 2745-9659

https://ijcis.net/index.php/ijcis/index

inventory can be used to decouple (separate) suppliers from the production process.

b. Inventory of semi-finished goods (working in process inventory). Are raw materials or components that have undergone several changes but have not been completed. The existence of work in process is caused by the time it takes to make a product (called cycle time). Reducing cycle time means reducing inventory.

c. Maintenance, repair and operation (maintenance, repair, operating, MRO) inventory. Maintenance, repairs, operations are used to keep machinery and production processes productive. MRO persists because the need and timing of maintenance and repair of some equipment is unknown.

d. Inventory of finished goods (finished goods inventory). Is a product that has been completed and waiting for delivery. Finished goods may be stored because future customer demands are not known.

According to Heizer and Render (2015) there are three basic costs associated with inventory: storage, transaction (Order), and shortage costs.

a. Storage Fee

The cost of keeping an item in inventory for a certain period of time, usually one year. Relates to physical ownership in storage. The costs include interest, insurance, taxes, depression, obsolescence, deterioration, spoilage, theft, damage, and warehousing costs (Heat, Lighting, Rent, Security)

b. Order Fee

Costs for ordering and receiving supplies. These costs vary with the actual order placement. In addition to shipping costs, these costs include determining how much is needed, preparing invoices, shipping costs, inspecting goods on arrival for quality and quantity, and moving goods to temporary storage.

c. Shortage Cost

Costs incurred when demand exceeds the supply of inventory on hand. These costs include the opportunity cost of not making a sale, lost customer goodwill, late charges, and similar costs (Heizer and Render, 2015).

\section{Raw Material Inventory}

The definition of raw materials according to Farah Margaret (2007) is "Inventories of raw materials are raw materials or additional materials owned by the company to be used in the production process activities, material inventory becomes the main component of a product." According to Freddy Rangkuti (2007) raw material inventory is "Inventory of raw materials has an important position in the company because the supply of raw materials has a very large influence on the smooth production."

From the above understanding, it can be concluded that the inventory of raw materials is the material used for the activities of the production process, because the supply of raw materials has a very large influence on the smooth production process.

According to Adisaputro and Asri in the Nathalia Journal (2012) the types of raw materials include:

a. Direct materials are all materials that are part of the finished goods produced. The costs incurred to purchase these direct materials have a close relationship and are proportional to the number of finished goods produced.

b. Indirect raw materials are raw materials that play a role in the production process but are not directly visible in the finished goods produced.

The factors that affect the supply of raw materials according to Awat 1999, namely:

a. Estimated need for raw materials

b. Durability or level of durability of the material

c. The length of the production process

d. Cost of storage carrying cost

e. Storage risk

f. Material price

g. Spending policy

h. Lead time waiting time

i. It's easy to get raw materials.

\section{Inventory Control}

According to Sofjan Assauri (2008) Raw material inventory control is an activity to determine the level and composition of the inventory of raw materials and manufactured goods so that the company can protect the smooth production effectively and efficiently. Inventory control is a series of control policies to determine the level of inventory that must be maintained, when orders to increase inventory must be made and how large orders must be held (Herjanto, 2008).

According to Assauri (2008) raw material inventory control aims to:

a. Take care not to let the company run out of inventory which can result in the cessation of the production process.

b. Keeping the inventory is not excessive so that the costs incurred do not become greater as well.

c. Keeping small purchases can be avoided because it results in high ordering costs.

Inventory control aims to determine and ensure the availability of the right inventory in the right quantity and at the right time. (Herjanto, 2008). 
International Journal of Computer and Information System (IJCIS)

Peer Reviewed - International Journal

Vol : Vol. 02, Issue 03, August 2021

e-ISSN : 2745-9659

https://ijcis.net/index.php/ijcis/index

\section{Economic Order Quantity (EOQ) Method}

According to Ahyari (1987) EOQ is the amount of material purchased that will be able to achieve the most minimal inventory costs. If a company does not buy raw materials very often and makes purchases in large quantities, inventory holding costs will be high because of the large investment in inventory (Carter, 2009).

According to Hansen and Mowen (2005) how many other order quantities might result in a lower total cost. The goal is to determine the order quantity that will minimize the total cost. This order quantity is called the Economic Order Quantity. The EOQ model is an example of a Push Inventory System.

The commonly used EOQ formula is:

$\mathrm{EOQ}=\sqrt{\frac{2(D)(S)}{c}}$

Where:

$\mathrm{EOQ}=$ Economic Order Quantity

$\mathrm{D}=$ Estimated usage or demand per time period

$\mathrm{S} \quad=$ Ordering cost (order preparation and machinery) per order

$\mathrm{C}=$ Storage cost per unit per year

The EOQ model above can be applied if the following assumptions are met:

a. The demand for the product is constant, uniform and known.

b. Price per unit is constant.

c. The holding cost per unit per year $(\mathrm{C})$ is constant

d. The ordering cost per order $(\mathrm{S})$ is constant.

e. The time between the order being placed and the items received is Constant

f. There is no shortage of materials or back orders.

According to Nilwan (2011), to determine the frequency of purchasing the most profitable merchandise, it can be done by dividing the need for merchandise for one period with the optimal purchase of merchandise. According to Robyanto and Dewi (2013), it is formulated as follows:

Purchase frequency $=$

Description:

$\mathrm{RU}=$ Total Raw Material Use

$\mathrm{EOQ}=$ order quantity or economic purchase

Total Inventory Cost (TIC) is the total cost of inventory issued (Assauri). To find out how much the total cost of inventory which consists of the cost of purchasing raw materials, ordering costs of raw materials and storage costs. The formula is as follows: The formula is as follows:

$T I C=\sqrt{2 \cdot D \cdot S \cdot H}$

Where:
TIC : Total Inventory Cost

$\mathrm{D}:$ : Estimated demand per period

$\mathrm{S}$ : Ordering cost per order

$\mathrm{H}$ : Storage cost per unit

According to Ahyari (1987) in general, to cope with the situation of running out of raw materials in the company, the company concerned will hold a security stock. This security inventory will be used by the company in the event of a shortage of raw materials, or delays in the arrival of raw materials purchased by the company. With the security inventory, the production process within the company will run without any disturbance in the absence of raw materials. Even though the raw materials ordered by the company were late from the calculated time.

According to Robyanto and Dewi (2013) it is formulated as follows: Safety stock = Average delay in raw materials per day $\mathrm{x}$ daily raw material requirements

According to Ahyari (1987) in carrying out repurchases, company management will consider the length of waiting time required in purchasing the raw materials. Thus, the repurchase carried out will be able to bring raw materials into the warehouse at the right time, so that there will be no shortage of raw materials due to delays in the arrival of raw materials or excess raw materials in the warehouse because the raw materials ordered came early.

According to Robyanto and Dewi (2013), it can be formulated as follows: Reorder Point $=$ Safety Stock + Raw material requirement during leadtime.

According to Simbar (2014) the maximum inventory is required by the company so that the amount of inventory in the warehouse is not excessive so that there is no waste of working capital. According to Robyanto and Dewi (2013), to find out the maximum amount of inventory, the following formula can be used:

Maxsimum Inventory $(\mathrm{MI})=\mathrm{SS}+\mathrm{EOQ}$

Description:

$\mathrm{SS}=$ Security Stock

EOQ = Economic Order or Purchase Quantity

\section{RESEARCH METHODS}

$\mathrm{CV}$. $\mathrm{XYZ}$ is a digital printing company which is located at J1. Sunan Abinawa, Patebon District, Kendal Regency (in front of SMP 2 Patebon). The beginning of the establishment of CV. XYZ in 2018. Founded by 3 people, namely Nur Setyani, Lukman Hakim, and Abdul Ghoni. With the experience of the three people, CV. XYZ started operating with a total of 6 employees, Nur Setyani is the owner of the digital printing company Trend in Kaliwungu who wants to expand her business, while Lukman Hakim has worked in photocopying for several years and then founded his 
International Journal of Computer and Information System (IJCIS)

Peer Reviewed - International Journal

Vol : Vol. 02, Issue 03, August 2021

e-ISSN : 2745-9659

https://ijcis.net/index.php/ijcis/index

own photocopying business which has two branches and then wants to try a new business that is still related. with photocopy. Meanwhile, Abdul Ghoni is one of the community leaders who is known to many people. After one year running, CV. XYZ was taken over by Lukman Hakim. Following the development of CV. $\mathrm{XYZ}$ accepts all orders for digital printing such as Brochures, Posters, Mugs, Pins, Keychains, Invitations, X-Banners, MMT, Business Cards, and Stickers with 42 employees.

This research is focused on the policy of procurement of raw material inventory carried out by CV. XYZ. To facilitate the analysis and discussion of the research results, the following will present a description of the existing data regarding the amount of raw material purchases, the amount of raw material usage, the frequency of purchasing raw materials, storage costs, ordering costs and the price of each raw material used by CV. XYZ.

\section{Raw Material Purchase}

\section{RESULTS AND DISCUSSION}

According to an interview with one of the employees at CV. XYZ, that the raw materials used are ivory paper, ink and other materials for mmt. CV. XYZ procures raw materials by ordering once a month.

According to Ekasari (2015) the data obtained from the company regarding data on raw material needs in 2017 were selected according to the assumptions of the application of the Economic Order Quantity (EOQ) method, namely:

a. Only one item (product) is considered.

b. The purchase price of materials per boarding unit.

c. The materials needed are always available in the market whenever they are needed.

d. The lead time is constant.

e. Each order is received in one delivery and can be used immediately.

f. There are only 3 kinds of costs, namely: the price of goods, the cost of storage, and the cost of ordering.

From these assumptions, the raw material in the form of ivory paper was chosen. The data obtained from CV. XYZ can be seen in the table below:

Table 1. Purchase of Paper Raw Materials in 2019

\begin{tabular}{|l|l|c|c|c|}
\hline No & Month & $\begin{array}{c}\text { Number of } \\
\text { Requirements } \\
(\text { Rim })\end{array}$ & $\begin{array}{l}\text { Price } \\
(\text { Rim) }\end{array}$ & $\begin{array}{c}\text { Total Price } \\
\text { (Rim) }\end{array}$ \\
\hline 1 & January & 3 & 350.000 & 1.050 .000 \\
\hline 2 & February & 3 & 350.000 & 1.050 .000 \\
\hline 3 & March & 4 & 350.000 & 1.400 .000 \\
\hline 4 & April & 5 & 350.000 & 1.700 .000 \\
\hline 5 & May & 5 & 350.000 & 1.700 .000 \\
\hline
\end{tabular}

\begin{tabular}{|c|l|c|c|c|}
\hline 6 & June & 4 & 350.000 & 1.400 .000 \\
\hline 7 & July & 5 & 350.000 & 1.700 .000 \\
\hline 8 & August & 4 & 350.000 & 1.400 .000 \\
\hline 9 & September & 3 & 350.000 & 1.050 .000 \\
\hline 10 & October & 4 & 350.000 & 1.400 .000 \\
\hline 11 & November & 4 & 350.000 & 1.400 .000 \\
\hline 12 & December & 5 & 350.000 & 1.700 .000 \\
\hline & Total & 49 & & 17.150 .000 \\
\hline
\end{tabular}

Table 2. Remaining Use of Paper Raw Materials in 2019

\begin{tabular}{|c|l|c|c|c|}
\hline No & Month & $\begin{array}{c}\text { Number of } \\
\text { equirements } \\
\text { (Rim) }\end{array}$ & $\begin{array}{c}\text { Usage per } \\
\text { day }\end{array}$ & emainder \\
\hline 1 & January & 3 & 2,8 & 0,2 \\
\hline 2 & February & 3 & 2,8 & 0,2 \\
\hline 3 & March & 4 & 3,9 & 0,1 \\
\hline 4 & April & 5 & 4,9 & 0,1 \\
\hline 5 & May & 5 & 4,7 & 0,3 \\
\hline 6 & June & 4 & 3,7 & 0,3 \\
\hline 7 & July & 5 & 4,8 & 0,2 \\
\hline 8 & August & 4 & 3,9 & 0,1 \\
\hline 9 & September & 3 & 2,9 & 0,1 \\
\hline 10 & October & 4 & 3,8 & 0,2 \\
\hline 11 & November & 4 & 3,9 & 0,1 \\
\hline 12 & December & 5 & 4,6 & 0,4 \\
\hline & Total & 49 & 46,7 & 2,3 \\
\hline
\end{tabular}

In Table 1. above can be presented data on purchases made by the company for a year which is carried out every month with a purchase frequency of 1 time a month or 12 times a year. The table above also presents the amount of ivory paper that the company buys and details the price each month. While in Table 2. it is presented that in 2019 the company used 46.7 Rim of raw materials, meaning that the remaining material use for a year was $2.3 \mathrm{Rim}$.

\section{Storage Fee}

The cost of keeping an item in inventory for a certain period of time, usually one year. Associated with physical ownership in storage (Heizer and Render, 2015). Based on observations in CV. XYZ costs include electricity costs, labor costs, equipment repair costs.

\section{Order Fee}

Costs associated with ordering raw materials. These costs vary with actual order placement (Heizer and Render, 2015). Based on observations in CV. XYZ in addition to shipping costs, these costs include telephone costs and administrative costs. 
International Journal of Computer and Information System (IJCIS)

Peer Reviewed - International Journal

Vol : Vol. 02, Issue 03, August 2021

e-ISSN : 2745-9659

https://ijcis.net/index.php/ijcis/index

a. Order Fee

1. Telephone Fee

2. Administration Fee $200,000 \times 12$

b. Saving Fee
1. Electricity costs
2. Labor Cost $1,500,000 \times 6$ people
3. Building tax costs Total
Rp. $1.500,000$
Rp. $9,000,000$
Rp. 300,000+
Rp 10,800,000

Rp. $1,500,000$

Rp. $2,400,000+$

Rp. 3,900,000

Ordering cost per order (S)

$$
\begin{aligned}
& =\frac{3.900,000}{12} \\
& =\text { Rp. } 325,000
\end{aligned}
$$

Storage Cost per unit of raw material $(\mathrm{H})$

$$
\begin{aligned}
& =\frac{11.000 .000}{46,7} \\
& =\text { Rp. } 235.546
\end{aligned}
$$

CV. XYZ purchases raw materials for ivory paper for a year with a purchase frequency of 12 times a year. So that it can result in the cost of ordering costs and storage costs. Then it can be seen that the ordering costs are Rp. 325,000 and storage costs are Rp. 235,546 in a year.

\section{Calculation of Total Inventory Cost Based on Company Policy}

CV. XYZ in holding raw material inventory, the company will reduce orders when the price of raw materials rises and will increase the number of orders for raw materials if the price decreases. This will cause the company to have to bear higher storage costs due to stockpiling of raw materials at a certain time. The data is obtained verbally that the company places an order once a month or 12 times a year.

According to Nissa (2017) to calculate the total cost of inventory, it is known as follows:

a. Total Raw Material Use 46.7 Rim

b. Storage Fee (H) Rp235.546

c. Ordering fee per order (S) IDR 325,000

d. Purchase Frequency 12 times

Calculation of the total cost of inventory (TIC) of raw materials, as follows:

$$
\begin{aligned}
\text { TIC } & =(\text { Average usage })(\mathrm{C})+(\mathrm{P})(\mathrm{F}) \\
& =(46,7)(235,546)+(325,000)(12) \\
& =10,999,999+3,900,000 \\
& =\text { Rp. } 14,899,999
\end{aligned}
$$

\section{Calculation of Raw Material Order Quantity with EOQ Method}

a. Calculation of purchasing raw materials
According to Hansen and Mowen (2005) some other order quantities may result in lower total costs. The goal is to determine the order quantity that will minimize the total cost. This order quantity is called the Economic Order Quantity.

Purchase of raw materials is based on:

1) Total Raw Material Usage per year (D) 46.7 Rim

2) Ordering fee per order (S) IDR 325,000

3) Storage fee (H) Rp235.546

Based on the data above, According to Salesti (2014) it can be formulated as follows:

$$
\begin{aligned}
E O Q & =\sqrt{\frac{2 D S}{H}} \\
& =\sqrt{\frac{2.46,7.325 .000}{235.546}} \\
& =\sqrt{128,870}=11,35
\end{aligned}
$$

b. Purchase Frequency

According to Robyanto and Dewi (2013), it is formulated as follows: Purchase frequency

$$
\begin{aligned}
& \frac{R U}{E O Q} \\
= & \frac{46_{z} 7}{11_{z} 35}=4 \text { times ordering }
\end{aligned}
$$

So, the remaining yarn raw material that has been calculated using the EOQ method is EOQ $x$ Purchase Frequency

$=11.35 \times 4$

$=45.4$

If an efficient and profitable purchase of raw materials is made, the company only purchases raw materials 4 times a year with a total inventory of 11.35 Rim.

c. Safety Stock

According to Robyanto and Dewi (2013) it is formulated as follows: Safety Stock $=$ Average delay in raw materials per day $\mathrm{x}$ daily raw material requirements

$=2$ days $\mathrm{x} 3.8$

$=7.6 \mathrm{Rim}$

The average minimum inventory owned by the company does not exist, while by carrying out an efficient supply of raw materials, the safety stock that should be applied to the company is 7.6 Rim. According to Ahyari (1987) in general, to cope with a state of running out of raw materials in the company, the company concerned will hold a security stock.

This security inventory will be used by the company in the event of a shortage of raw materials, or delays in the arrival of raw materials purchased by the 
International Journal of Computer and Information System (IJCIS)

Peer Reviewed - International Journal

Vol : Vol. 02, Issue 03, August 2021

e-ISSN : 2745-9659

https://ijcis.net/index.php/ijcis/index

company. Safety stock is a limit on the amount of inventory that must always be available or available at any time in a company which is used to prevent scarcity/shortage of inventory (Robyanto, 2013).

\section{d. Reorder (Reorder Point)}

According to Robyanto and Dewi (2013), it can be formulated as follows: Reorder point $=$ Safety Stock + Raw material requirement during leadtime $=7.6+7.6$

$=15.2 \mathrm{Rim}$

The company reorders when the yarn raw material inventory is running out. Meanwhile, by carrying out an efficient analysis of raw material inventory. The company must hold a reorder when the supply of raw materials for yarn is $15.2 \mathrm{Rim}$.

Based on this, there is an efficient monitoring of raw material inventory. So storage costs and the risk of shrinking the quality of raw materials and the occurrence of shortages of raw materials due to delays in the arrival of raw materials can be minimized. This is according to According to Ahyari (1987) in carrying out repurchases. The company's management will consider the length of waiting time required in purchasing these raw materials.

Thus, the repurchase carried out will be able to bring raw materials into the warehouse at the right time, so that there will be no shortage of raw materials due to delays in the arrival of raw materials or excess raw materials in the warehouse because the raw materials ordered arrived early (Ahyari, 1987).

e. Determining the Amount of Inventory Cost

According to Andira (2016) in calculating the cost of inventory for the purchase of materials, the following formula is used:

TIC $=$ Total Inventory Cost

1) Total Raw Material Use (D) 46.7 Rim

2) The cost of ordering each time an order (S) Rp. 325,000 Rim

3) Storage fee $(\mathrm{H}) \mathrm{Rp} 235.546$

$$
\begin{aligned}
\mathrm{TIC} & =\sqrt{2 \cdot D \cdot S \cdot H} \\
& =\sqrt{2.46,7.325 \cdot 000 \cdot 235.546} \\
& =\sqrt{7,14999} \\
& =2,6739
\end{aligned}
$$

f. Determination of Maximum Inventory (Maximum Inventory)

According to Robyanto and Dewi (2013) to find out the maximum amount of inventory can be used the formula:

Maximum Inventory $=$ SS + EOQ

$$
=7.6+11.35
$$$$
=18.94 \mathrm{Rim}
$$

The maximum inventory the company has is none. Meanwhile, by carrying out an efficient analysis of raw materials. Then the maximum amount of inventory that should be maintained by the company per day is 8,529.33 Rim.

So that the company does not procure excessive raw materials, so it can reduce storage costs so that the company can allocate funds or capital for other purposes.

\section{CONCLUSIONS AND SUGGESTIONS}

\section{Conclusions}

Based on the results of research and data analysis of the application of the economic order quantity (EOQ) method in CV. XYZ can produce inventory cost efficiency. So it can be concluded that the policy of raw material procurement carried out by $\mathrm{CV}$. XYZ so far has not been efficient and has not shown minimum costs. While the inventory costs that have been issued by the company are still greater when compared to companies implementing raw material inventory control using the EOQ method.

In using the company's policy, the total inventory of paper raw materials is 46.7 and the company places an order once a month or 12 times a year. The total cost of inventory issued based on company policy is Rp. $14,899,999$, while by using the EOQ calculation method the total inventory of paper raw materials can be made smaller, namely as much as 45.4 with orders 4 times a year.

\section{Suggestions}

Based on the analysis and research conclusions, in this section the author tries to provide suggestions that are expected to be useful for the company in the future.

a. The company should review the policies implemented by the company in relation to controlling raw material inventory

b. The use of the economic order quantity (EOQ) method can determine inventory according to the company's needs but still pay attention to safety stock so that it can reduce losses that occur due to the company's lack of proper management or control of its inventory.

c. The company should determine the amount of safety stock and re-order point in controlling raw material inventory to protect or maintain the possibility of a raw material shortage that is greater than expected and to prevent delays in the raw material ordered. 
International Journal of Computer and Information System (IJCIS)

Peer Reviewed - International Journal

Vol : Vol. 02, Issue 03, August 2021

e-ISSN : 2745-9659

https://ijcis.net/index.php/ijcis/index

\section{REFERENCES}

[1] Ana, S.E. 2018 Analisis Pemesanan Bahan Baku Optimal Percetakan Merbu Dengan Metode Economic Order Quantity. Fakultas Ekonomi Universitas Sebelas Maret, Surakarta.

[2] Ahyari, Agus. 1987. Manajemen Produksi Pengendalian Produksi. Yogyakarta.

[3] Assauri, Sofjan.2008. Manajemen Produksi dan Operasional. Lembaga penerbit Fakultas Ekonomi Universitas Indonesia. Jakarta.

[4] Freddy Rangkuti. 2007. Manajemen Persediaan :Aplikasi di Bidang Bisnis. Edisi 2 Jakarta: PT. Raja Grafindo Persada.

[5] Heizer Jay, Render Barry 2005. Operations Management. Jakarta

[6] Saraswati, S.D. 2018. Analisis Perhitungan Economic Order Quantity (EOQ) Sebagai Pengendalian Persediaan Bahan Baku (Study pada PT Iskandar Indah Printing Textile). Fakultas Ekonomi dan Bisnis Islam.Surakarta.

[7] Stevenson, W.J., Chuong, S.C. 2014. Manajemen Operasi Perspektif Asia,Edisi 9, Salemba Empat and MC Graw Hill Education. Jakarta.

[8] Yatmoko, A.W.2017. Pengendalian Persediaan Bahan Baku Pthalic Anhydride Menggunakan Metode Economic Order Quantity (EOQ) Studi Kasus di PT. Alkindo Mitraraya. Kerja Praktek. Fakultas Teknik Universitas Mercu Buana, Jakarta. 